\title{
SEROPREVALENCE OF HEPATITIS B AND C INFECTION MARKERS AMONG CHILDREN AND ADOLESCENTS IN THE SOUTHERN BRAZILIAN REGION
}

Andréa do LIVRAMENTO(1), Caio Mauricio Mendes de CORDOVA(2), Celso SPADA(3) \& Arício TREITINGER(3)

\begin{abstract}
SUMMARY
Hepatitis B virus (HBV) and hepatitis C virus (HCV) infections account for a substantial proportion of liver diseases worldwide. The aim of this study was to determine the prevalence of HBV and HCV serological markers among children and adolescents and verify the epidemiology of the $\mathrm{HBV}$ infection over than a decade of the introduction of vaccination program. Serologic markers to HBsAg, total anti-HBc and anti-HCV had been tested in 393 samples. The seropositivity for HBsAg was $0.76 \%$ and for total anti$\mathrm{HBc}$ was $1.02 \%$. Copositivity between $\mathrm{HBsAg}$ and total anti-HBc was verified in $0.76 \%$ of the analyzed samples. There was no seropositivity for anti-HCV marker. The seroprevalence of HBV infection markers among children and adolescents in the southern Brazilian region is high compared to that reported in other countries. Preventive measures, such as educational activities in addition to the universal childhood HBV vaccination, should be initiated in order to reduce the morbimortality and the economic burden associated with the disease.
\end{abstract}

KEYWORDS: Adolescents; Hepatitis B; Hepatitis C.

\section{INTRODUCTION}

Hepatitis B virus (HBV) and hepatitis C virus (HCV) infections account for a substantial proportion of liver diseases worldwide. An estimated amount of two billion people have been infected with the hepatitis B virus and over 350 million have chronic liver infections. About $25 \%$ of adults who become chronically infected during childhood die from HBV-related liver cancer or cirrhosis ${ }^{45}$. HCV infections are also common worldwide. It is estimated that about $3 \%$ of the world's population has been infected with $\mathrm{HCV}$ and that some 170 million are chronic carriers at risk of developing liver cirrhosis and/or liver cancer. These chronic carriers represent a reservoir sufficiently large for $\mathrm{HCV}$ to persist ${ }^{44}$.

The hepatitis B virus carrier rate variation is $1-20 \%$ worldwide. This variation is related to differences in the route of transmission and the patient's age at infection. In the areas of low prevalence (rate of $0.1-2 \%$ ), the sexual and percutaneous transmission during adulthood are the main ways of transmission. In areas of intermediate prevalence (rate of 3-5\%), the sexual, percutaneous and transmission during delivery are the major routes. In areas of high prevalence (rate of 10-20\%), the predominant mode of transmission is perinatal, and the disease is transmitted vertically during early childhood from the mother to the infant $\mathrm{t}^{31}$.

Although HCV infection has both acute and chronic forms, most of the morbidity associated with infection is realized through the development of chronic liver disease in a subset of infected people, years after initial acquisition of the infection. Thus, a major determinant of the future burden of disease is the past and present incidence of infection. However, establishing the incidence of $\mathrm{HCV}$ infection is difficult because most infections are initially asymptomatic and available assays do not distinguish acute from chronic or resolved infection. Acute disease reporting systems can underestimate the incidence of $\mathrm{HCV}$ infection, even in countries with well-established surveillance systems ${ }^{35}$.

In Brazil, the HBV vaccine was included in the National Immunization Program in 1996, but was implemented in the State of Santa Catarina in 1993 for children under five years of age and for professionals at risk $^{27}$. The hepatitis B immunization schedule for newborns consists of three doses $(0,1,6$ month schedule). Besides, the program includes the prevention of perinatal infection, through maternal screening and prophylaxis of newborns, HBV vaccination for all children, to prevent the infection in childhood and older, vaccination of adolescents who were not protected and individuals belonging to risk groups. One of the goals of the Brazilian Health Ministry is the immunization of young people under 19 years of age ${ }^{15,27}$.

The HBV universal vaccination has demonstrated reduction in rates of infection. However, after the implementation of the vaccination routine, it seems useful to verify the impact of routine immunization on the epidemiology of the infection by analyzing the trend and the change of several indicators, through serum-epidemiological studies ${ }^{7,10}$. Thus, after over than a decade of the introduction of vaccination program against

(1) Programa de Pós-graduação em Farmácia, Universidade Federal de Santa Catarina, UFSC, Florianópolis, SC, Brasil.

(2) Departamento de Ciências Farmacêuticas, Fundação Universidade Regional de Blumenau, FURB, Blumenau, SC, Brasil.

(3) Departamento de Análises Clínicas, Universidade Federal de Santa Catarina, UFSC, Florianópolis, SC, Brasil.

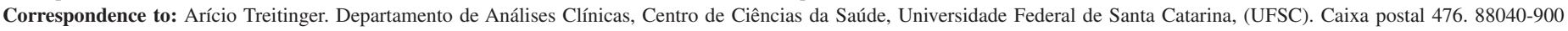
Florianópolis, SC, Brasil. E-MAIL: deia.liv@terra.com.br 


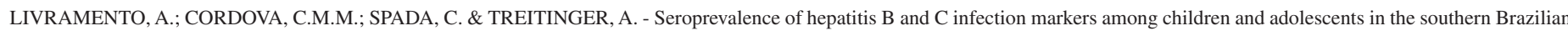
region. Rev. Inst. Med. Trop. São Paulo, 53(1): 13-7, 2011.

$\mathrm{HBV}$ in Brazil ${ }^{27}$, it is necessary to verify the impact of this practice in the epidemiology of infection in the country.

Epidemiological surveillance for hepatitis $\mathrm{C}$ is also essential, even if there is no vaccine available. Identification of $\mathrm{HCV}$-infected people is required to initiate prevention activities and reduce the risks for $\mathrm{HCV}$ transmission and chronic liver disease. Anti-HCV-positive individuals require further evaluation for chronic $\mathrm{HCV}$ infection and liver disease, and those with chronic hepatitis $\mathrm{C}$ require evaluation for possible antiviral therapy and the need for further medical management ${ }^{8}$.

In this study, the aim is to determine the prevalence of HBV and HCV serological markers among children and adolescents and verify the epidemiology of the HBV infection over than a decade of the introduction of vaccination program.

\section{MATERIALS AND METHODS}

Study design: We conducted a cross-sectional study to evaluate the prevalence of serological markers for HBV and HCV among children and adolescents.

Studied population: The amostral size was calculated based on the statistical formula $\mathrm{n} \cong 4 \mathrm{z}_{\alpha}{ }^{2} \mathrm{p} \mathrm{q} /(2 \mathrm{ME})^{2}$, being $\mathrm{z}_{\alpha}=\mathrm{z}$ value of the normal curve in the (usually bicaudal), $\mathrm{p}=$ initial estimate of the proportion, $\mathrm{q}=$ p-complement $(1-p)$ and $\mathrm{ME}=$ margin of error on the maximum tolerable parameter ${ }^{28}$. Considering 0.5 the initial estimate of the proportion and the complement of $\mathrm{p}$ equal to 0.5 , with prevalence of $\mathrm{HBV}$ and $\mathrm{HCV}$ markers of $50 \%$ with a $95 \%$ confidence interval and 0.05 alpha error, it was demonstrated to be necessary 384 participants. An amostral plan was designed, aiming to reproduce the distribution of the population of children and adolescents attended by the Programa de Saúde da Família in health posts in the city of Blumenau. It was evaluated about 10 to 30 volunteers in each health unit visited, being those 17 out of 40 . The sample was composed of 393 children and adolescents attended at these health institutions in the period between October 2007 and August 2008. The participants were included by randomized selection.

Data processing and analysis: Inclusion criteria were age between 10 to 15 years and presentation of an informed consent signed by parents or responsible ones.

Blood samples were collected by venipuncture in the health institutions selected for the survey, to determine the serologic markers $\mathrm{HBsAg}$, total anti-HBc and anti-HCV. After separation of the serum, the samples were stored at $-20^{\circ} \mathrm{C}$ to perform the serological tests. The analysis of blood samples was performed in the Municipal Laboratory of the city of Blumenau, Santa Catarina State, Brazil.

Vaccination data of the participants who had presented hepatitis B virus infection markers had been verified in the vaccination document. All participants who were positive for $\mathrm{HBV}$ infection markers had presented three doses of vaccine in the vaccination certificate.

Serologic testing: $\mathrm{HBsAg}$, total anti-HBc and anti-HCV were detected by Microparticle Enzyme Immunoassay (MEIA) with commercial kits AxSym ${ }^{\circledR}$ (Abbott Diagnostics, Chicago, Illinois, USA). The MEIA is a variation of the principle of Enzyme Immunoassay (EIA) and the solid phase comprises microparticles that increase the sensitivity of the method. This solid phase EIA uses the antigens and/or antibody adsorbed on the surface for the binding of complementary analytes. The bound analyte is detected by a number of antibody-antigen reactions. The EIA that qualitatively detects the surface antigen of hepatitis B virus (HBsAg) in human serum or plasma uses microparticles coated with anti-HB monoclonal antibodies. In the same way, those who qualitatively detect the total anti-HBc and anti-HCV recombinant antigens have adsorbed the microparticles in the solid phase.

Ethical approval: This study was approved by the Ethics Committee in Human Research at the Federal University of Santa Catarina, in the Protocol n. 238/07, and approved by the Health Secretary in Blumenau.

\section{RESULTS}

The population was composed of 393 children and adolescents. Among the participants, 210 were female (53.44\%) and 183 were male $(46.56 \%)$. The age range was 10 - 15 years, and the mean age was 12.5 years $( \pm 1.7)$. The most frequent age group was between 12 and 13 years $(40.20 \%)$. Table 1 refers to the general characterization of the sample, with the population distribution according to sex and age.

Table 1

Population distribution according to sex and age

\begin{tabular}{lc}
\hline Variable & Population \\
\hline Sex & \\
Female & $210(53.44 \%)$ \\
Male & $183(46.56 \%)$ \\
Age (years) & \\
$10-11$ & $105(26.72 \%)$ \\
$12-13$ & $158(40.20 \%)$ \\
$14-15$ & $130(33.08 \%)$ \\
\hline
\end{tabular}

The seropositivity for HBsAg was found in $0.76 \%$ of the samples (3/393) and total anti-HBc was $1.02 \%$ (4/393). Copositivity between HBsAg and total anti-HBc was detected in $0.76 \%$ (3/393). The seropositivity for $\mathrm{HBV}$, which means positive samples that reacted with one or two tested markers (HBsAg and total anti-HBc), was $1.02 \%$ (4/393) (Table 2). In the evaluation of the 393 samples for anti-HCV, no case of positivity for the antibody was found.

Table 2

HBV markers in the studied population

\begin{tabular}{lcc}
\hline Serologic marker & Positive $(\mathrm{n})$ & $\%$ \\
\hline Total anti-HBc & 1 & $0.25 \%$ \\
Total anti-HBc $+\mathrm{HBsAg}$ & 3 & $0.76 \%$ \\
No marker & 389 & $98.98 \%$ \\
\hline
\end{tabular}

All volunteers that were positive for HBsAg marker received three doses of hepatitis B vaccine. 


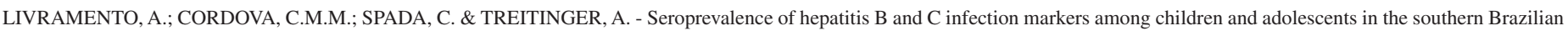
region. Rev. Inst. Med. Trop. São Paulo, 53(1): 13-7, 2011.

\section{DISCUSSION}

Chronic HBV and HCV infections are the most important causes of hepatocellular carcinoma (HCC), the fifth most common solid tumor in the world. The incidence and prevalence of HCC is rising in the United States and in Europe, and costs of care in HCC will continue to rise ${ }^{14}$. In the United States, the total economic burden of HCC in 2005 was estimated to be $\$ 454.5$ million $^{22}$. The development of more effective and cost-effective treatments for viral hepatitis and related complications is a challenge for the medical community ${ }^{23}$. Therefore, interventions to reduce the prevalence of $\mathrm{HBV}$ and $\mathrm{HCV}$ infections may yield substantial economic benefits.

The seroprevalence of anti-HCV among children and adolescents found in this study is in agreement with that observed in Spain $^{32}$, and lower than that reported in the United States ${ }^{20}$, in Germany ${ }^{16}$ and in Pakistan ${ }^{19}$. The results of our study show a low circulation of the hepatitis $\mathrm{C}$ virus among the studied population, possibly due to the low exposure to risk factors for $\mathrm{HCV}$ infection. The risk factors most frequently cited as accounting for $\mathrm{HCV}$ transmission worldwide are injecting drug use and blood transfusions ${ }^{4,11,12}$.

There is a lack of data about HCV infection in pediatric and adolescent population in Brazil. Anti-HCV seroprevalence reports in Blumenau are available among people submitted to blood testing in a laboratory $(1.6 \%)^{21}$ and blood donors $(0.59 \%)^{33}$. Studies among blood donors revealed an overall confirmed anti-HCV seroprevalence of $0.35 \%$ in Santa Catarina ${ }^{33}$, $0.9 \%$ in Rio de Janeiro ${ }^{2}$ and $1.2 \%$ in Ribeirão Preto ${ }^{42}$. In a multi-center study of HCV seroprevalence among first time Brazilian blood donors, the frequency of anti-HCV was $0.97 \%$ in women and $0.38 \%$ in men $^{29}$. In relation to adult populations, the awareness of $\mathrm{HCV}$ infection among children and adolescents is limited. Nevertheless, compared to adults, the prevalence of this infection was lower, and horizontal transmission from adult to child in a household does not appear to be an important risk factor in the studied population.

The prevalence for $\mathrm{HBsAg}$ and for total anti-HBc reported here was higher than that found among adolescents in Portugal ${ }^{3}$ and among children and adolescents under 15 years of age in Saudi Arabia ${ }^{26}$. The prevalence of these markers reflects a higher exposure to risk factors for $\mathrm{HBV}$ infection in the studied population. Moreover, low educational level, low socio-economic status and perinatal transmission may also be associated with the higher prevalence. However, hepatitis B infection is more commonly transmitted in children through the horizontal route ${ }^{1,13,30}$.

Although the vaccination is the most effective strategy to prevent HBV infection, in our study half of non-infected participants showed antibodies to hepatitis B surface antigen below $10 \mathrm{mIU} / \mathrm{mL}$ (data not shown), and we found three cases of HBsAg in vaccinated individuals. These individuals may not have received the hepatitis $B$ vaccine at birth and may have been exposed to the virus before vaccination. Furthermore, some other hypothesis such as mutations in the virus surface antigen ${ }^{18}$ and intrauterine transmission of HBV from mothers to the fetus ${ }^{40}$ have been proposed to explain the HBV infection in vaccinated individuals. In this study, transmission of HBV to infants born from HBV carrier mothers cannot be ruled out. However, HBsAg status of mothers was not established. In addition, another limitation is the lack of virological data investigating possible vaccine escape mutants.
In the present study, the prevalence for anti-HBc alone was $0.25 \%$. Worldwide, the prevalence of isolated anti-HBc in different populations ranged from 0.1 to $20 \% \%^{9,17,36,41}$. In Taiwan, one study with 1200 children aged seven years with complete HBV immunization in infancy showed that eleven children had new HBV infections with anti-HBc positivity as the only marker, and none became positive for HBsAg or had detectable HBV DNA by polymerase chain reaction. The percentage of protective anti-HBs in children without booster vaccination decreased from $71.1 \%$ at age seven years to $37.4 \%$ at age 12 years, but only one of 200 children who received a booster dose and two of 258 children who did not received had developed new anti-HBc positivity ${ }^{24}$. National vaccination program has decreased the spread of anti-HBc alone in this country ${ }^{25}$. In a 10-year follow-up study conducted in a community with a high spread of HBV infection, $0.8 \%$ had developed anti-HBc yet none showed a clinically significant breakthrough infection ${ }^{43}$. Another study showed that three out of 19,000 individuals who had developed HCC were HBsAg negative but were anti-HBc positive. This might suggest that there is a very small risk of $\mathrm{HCC}$ among those who have anti-HBc as the only indication of a previous infection ${ }^{6}$.

The present study showed that seropositivity for HBV infection among children and adolescents from Blumenau was lower than that recorded among people submitted to blood testing in a laboratory $(38.5 \%)^{21}$ and blood donors $(9.25 \%)^{33}$ in the same city. The overall prevalence rate of HBV infection in the studied population was also smaller than that found among blood donors in Santa Catarina $(5.35 \%)^{33}$, Rio de Janeiro $(3.68 \%)^{2}$, Acre $(54.8 \%)^{38}$ and Ribeirão Preto $(8.7 \%)^{42}$. Other authors have reported higher prevalence of HBV markers in older ages. In a rural area in the Amazon Region of Mato Grosso State, the overall seroprevalence of HBV markers was $40.0 \%{ }^{39}$. The prevalence of serological markers of HBV infection was $11.1 \%$ in healthcare workers in Mato Grosso do Sul State ${ }^{34}$, and $24.1 \%$ among laboratory staff in Goiânia $^{37}$. One study carried out among dentists from Campo Grande, Mato Grosso do Sul, showed $10.8 \%$ of seropositivity for HBV infection ${ }^{5}$.

The higher prevalence of HBV markers in older ages could be due to the greater number of years of potential exposure and the lack of awareness of HBV infection in earlier decades ${ }^{13}$. In addition, the vaccination may have contributed to this lower prevalence among children and adolescents aged 10-15 years. The low prevalence of HBV infection markers indicates the positive impact of routine infant hepatitis $B$ vaccination, which was included in the National Immunization Program in $1996^{27}$, in the prevention of transmission in the studied population.

In conclusion, the prevalence of HBV infection was higher than $\mathrm{HCV}$ infection in the studied population. Until a safe and effective vaccine against $\mathrm{HCV}$ is available, information and educational campaigns regarding modes of transmission are the main preventive tools to reduce the burden of $\mathrm{HCV}$ infection and HCV-related disease. The data from our study show that the seroprevalence of HBV infection markers among children and adolescents in the southern Brazilian region, over than a decade of the introduction of vaccination program, is higher when compared to the other countries. This result reinforces the importance of $\mathrm{HBV}$ vaccination initiated at birth, to prevent perinatal HBV transmission, and the necessity of preventive measures including educational activities in addition to the universal childhood HBV vaccination, to further reduce the morbimortality and the economic impact associated with the disease. 


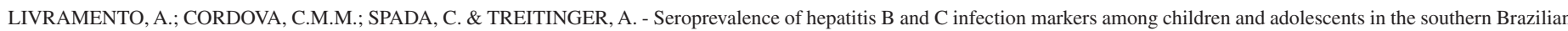
region. Rev. Inst. Med. Trop. São Paulo, 53(1): 13-7, 2011.

\section{RESUMO}

\section{Soroprevalência dos marcadores de infecção das hepatites B e C em crianças e adolescentes da região sul do Brasil}

As infecções pelo vírus da hepatite B (HBV) e pelo vírus da hepatite $\mathrm{C}(\mathrm{HCV})$ representam a causa de uma substancial proporção das doenças hepáticas em todo o mundo. O objetivo deste estudo foi determinar a prevalência dos marcadores sorológicos do HBV e do HCV em crianças e adolescentes, e verificar a epidemiologia da infecção pelo HBV passada uma década desde a introdução do programa de vacinação. Os marcadores sorológicos HBsAg, anti-HBc total e anti-HCV foram avaliados em 393 amostras. A soropositividade para o HBsAg foi de $0,76 \%$ e para o anti$\mathrm{HBc}$ total foi de $1,02 \%$. Co-positividade entre $\mathrm{HBsAg}$ e anti-HBc total foi verificada em $0,76 \%$ das amostras analisadas. Não houve soropositividade para o marcador anti-HCV. A soroprevalência dos marcadores de infecção pelo HBV em crianças e adolescentes da região sul do Brasil é elevada em relação à reportada em outros países. Medidas preventivas, tais como atividades educativas além da vacinação infantil universal contra o HBV, devem ser iniciadas a fim de reduzir a morbimortalidade e o impacto econômico associados a doença.

\section{ACKNOWLEDGMENTS}

We thank all the volunteers who participated in this study, the Health Secretary of Blumenau and health workers.

\section{REFERENCES}

1. Al-Faleh FZ, Al-Jeffri M., Ramia S, Al-Rashed R, Arif M, Rezeig M., et al. Seroepidemiology of hepatitis B virus infection in Saudi children 8 years after a mass hepatitis B vaccination programme. J Infect. 1999;38:167-70.

2. Andrade AFB, Oliveira-Silva M, Silva SGC, Motta IJ, Bonvicino CR. Seroprevalence of hepatitis B and C virus markers among blood donors in Rio de Janeiro, Brazil, 1998-2005. Mem Inst Oswaldo Cruz. 2006;101:673-76.

3. Antunes H, Macedo M, Estrada A. Taxa de cobertura vacinal com imunização para o vírus da hepatite B. Acta Med Port. 2004;17:303-8.

4. Balogun MA, Laurichesse H, Ramsay ME, Sellwood J, Westmoreland D, Paver WK, et al. Risk factors, clinical features, and genotype distribution of diagnosed hepatitis $\mathrm{C}$ virus infections: a pilot for a sentinel laboratory-based surveillance. Commun Dis Public Health. 2003;6:34-9.

5. Batista SMF, Andreasi MSA, Borges AMT, Lindenberg AS, Silva, AL, Fernandes TL, et al. Seropositivity for hepatitis B virus, vaccination coverage, and vaccine response in dentists from Campo Grande, Mato Grosso do Sul, Brazil. Mem Inst Oswaldo Cruz. 2006;101:263-7.

6. Beasley RP, Hwang LY. Overview on the epidemiology of hepatocellular carcinoma. In: Hollinger FB, Lemon SM, Margolis H, editors. Viral hepatitis and liver disease. Baltimore: Williams \& Wilkins; 1991. p. 532-5.

7. Bonanni P, Pesavento G, Bechini A, Tiscione E, Manelli F, Benucci C, et al. Impact of universal vaccination programmes on the epidemiology of hepatitis B: 10 years of experience in Italy. Vaccine. 2003;21:685-91.

8. Centers for Disease Control and Prevention. Prevention and control of infections with hepatitis viruses in correctional settings. MMWR Recomm. Rep. 2003;52(RR-1):1-36.

9. Chan CY, Lee SD, Tsai YT, Lo KJ. Hepatitis B vaccination alone is not adequate for the categorizing of adult subjects with isolated anti-HBc. J Gastroenterol Hepatol. 1995; 10:192-7.
10. Chongsrisawat V, Yoocharoen P, Theamboonlers A, Tharmaphornpilas P, Warinsathien P, Sinlaparatsamee S, et al. Hepatitis B seroprevalence in Thailand: 12 years after hepatitis B vaccine integration into the national expanded programme on immunization. Trop Med Int Health. 2006;11:1496-502.

11. Dalgard O, Jeansson S, Skaug K, Rakmerud N, Bell H. Hepatitis C in the general adult population of Oslo: prevalence and clinical spectrum. Scand J Gastroenterol. 2003:38:864-70

12. Dore GJ, Law M, MacDonald M, Kaldor JM. Epidemiology of hepatitis C virus infection in Australia. J Clin Virol. 2003;26:171-84.

13. El Beltagy KE, Al Balawi IA, Almuneef M, Memish ZA. Prevalence of hepatitis B virus markers among blood donors in a tertiary hospital in Tabuk, northwestern Saudi Arabia. Int J Infect Dis. 2008;12:495-9.

14. El-Serag HB. Hepatocellular carcinoma: recent trends in the United States. Gastroenterology. 2004:127(5 Suppl 1):S27-34

15. Ferreira CT, Silveira TR. Hepatites virais: aspectos da epidemiologia e da prevenção. Rev Bras Epidemiol. 2004:7:473-87.

16. Gerner P, Wirth S, Wintermeyer P, Walz A, Jenke A. Prevalence of hepatitis C virus infection in children admitted to an urban hospital. J Infection. 2006;52:305-8.

17. Grob P, Jilg W, Bornhak H, Gerken G, Gerlich W, Günther S. et al. Serological pattern "anti-HBc alone" report on a workshop. J Med Virol. 2000;62:450-5.

18. Hsu HY, Chang MH, Ni YH, Lin HH, Wang SM, Chen DS. Surface gene mutants of hepatitis B virus in infants who develop acute or chronic infections despite immunoprophylaxis. Hepatology, 1997;26:786-91.

19. Jafri W, Jafri N, Yakoob J, Islam M, Tirmizi SF, Jafar T. et al. Hepatitis B and C: prevalence and risk factors associated with seropositivity among children in Karachi, Pakistan. BMC Infect Dis. 2006;6:101.

20. Jonas MM, Robertson LM, Middleman AB. Low prevalence of antibody to hepatitis C virus in an urban adolescent population. J Pediatr. 1997;131:314-6.

21. Ladehof ML, Bueno EC. Incidência de hepatites virais em Blumenau - SC, Brasil. Acta Farm Bonaerense. 2005;24:436-40.

22. Lang K, Danchenko N, Gondek K, Shah S, Thompson D. The burden of illness associated with hepatocellular carcinoma in the United States. J Hepatol. 2009;50:89-99.

23. Lavanchy D. Worldwide epidemiology of HBV infection, disease burden, and vaccine prevention. J Clin Virol. 2005;34(Suppl 1):S1-3

24. Lin YC, Chang MH, Ni YH, Hsu HY, Chen DS. Long-term immunogenicity and efficacy of universal hepatitis B virus vaccination in Taiwan. J Infect Dis. 2003;187:134-8.

25. Lu SN, Chen CH, Chen TM, Lee PL, Wang JH, Tung HD, et al. Hepatitis B virus infection in adolescents in a rural township - 15 years subsequent to mass hepatitis B vaccination in Taiwan. Vaccine, 2006;24:759-65.

26. Madani TA. Trend in incidence of hepatitis B vírus infection during a decade of universal childhood hepatitis B vaccination in Saudi Arabia. Trans R Soc Trop Med Hyg. 2007;101:278-83.

27. Ministério da Saúde. Programa Nacional de Imunizações. Brasília: Secretaria de Vigilância em Saúde; 2003. 208p.

28. Motta VT, Wagner MB. Bioestatística. Caxias do Sul: Educs; 2003. 201p

29. Nascimento MC, Mayaud P, Sabino EC, Torres KL, Franceschi S. Prevalence of hepatitis $\mathrm{B}$ and $\mathrm{C}$ serological markers among first-time blood donors in Brazil: a multi-center serosurvey. J Med Virol. 2008;80:53-7 
LIVRAMENTO, A.; CORDOVA, C.M.M.; SPADA, C. \& TREITINGER, A. - Seroprevalence of hepatitis B and C infection markers among children and adolescents in the southern Brazilian region. Rev. Inst. Med. Trop. São Paulo, 53(1): 13-7, 2011.

30. Odusanya OO, Alufohai FE, Meurice FP, Wellens R, Weil J, Ahonkhai VI. Prevalence of hepatitis B surface antigen in vaccinated children and controls in rural Nigeria. Int J Infect Dis. 2005;9:139-43.

31. Pyrsopoulos NT, Reddy KR. Hepatitis B. eMedicine, 2009. Available from: http:// emedicine.medscape.com/article/177632-overview. Accessed December 19, 2009.

32. Riestra S, Fernández E, Leiva P, Garcia S, Ocio G, Rodrigo L. Prevalence of hepatitis $\mathrm{C}$ virus infection in the general population of Northern Spain. Eur J Gastroenterol Hepatol. 2001;13:477-81

33. Rosini N, Mousse D, Spada C, Treitinger A. Seroprevalence of HBsAg, Anti-HBc and Anti-HCV in Southern Brazil, 1999-2001. Braz J Infect Dis. 2003;7:262-7.

34. Sanches GBS, Honer MR, Pontes ERJC, Aguiar JI, Ivo ML. Caracterização soroepidemiológica da infecção pelo vírus da hepatite B em profissionais de saúde da atenção básica no Estado de Mato Grosso do Sul, Brasil. Rev Panam Infectol. 2008;10:17-22.

35. Shepard CW, Finelli L, Alter MJ. Global epidemiology of hepatitis C virus infection. Lancet Infect Dis. 2005;5:558-67.

36. Silva AE, McMahon BJ, Parkinson AJ, Sjogren MH, Hoofnagle JH, Di Bisceglie AM. Hepatitis B virus DNA in persons with isolated antibody to hepatitis B core antigen who subsequently received hepatitis B vaccine. Clin Infect Dis. 1998;26:895-7.

37. Silva PA, Fiaccadori FS, Borges AMT, Silva SA, Daher RR, Martins RM, et al. Seroprevalence of hepatitis B virus infection and seroconvertion to anti-HBsAg in laboratory staff in Goiânia, Goiás. Rev Soc Bras Med Trop. 2005;38:153-6.
38. Silva RSU, Ribeiro SAL, Silveira RP, Freitas MS. Avaliação da pré-triagem sorológica para o marcador do vírus da hepatite $\mathrm{B}$ (anti-HBc total) em candidatos à doação de sangue no Estado do Acre, 2002. Rev Soc Bras Med Trop. 2006;39:179-82.

39. Souto FJD, Fontes CJF, Oliveira SS, Yonamine F, Santos DRL, Gaspar AMC. Prevalência da hepatite B em área rural de município hiperendêmico na Amazônia Mato-grossense: situação epidemiológica. Epidemiol Serv Saúde. 2004;13:93-102.

40. Tang SX, Yu GL. Intrauterine infection with hepatitis B virus. Lancet. 1990;335:302.

41. Ural O, Findik D. The response of isolated anti-HBc positive subjects to recombinant hepatitis B vaccine. J Infect. 2001;43:187-90.

42. Valente VB, Covas DT, Passos ADC. Marcadores sorológicos das hepatites B e C em doadores de sangue do Hemocentro de Ribeirão Preto, SP. Rev Soc Bras Med Trop. $2005 ; 38: 488-92$

43. Wainwright RB, Bulkow LR, Parkinson AJ, Zanis C, McMahon BJ. Protection provided by hepatitis B vaccine in a Yupik Eskimo population: results of a 10-year study. J Infect Dis. 1997;175:674-7.

44. World Health Organization. Hepatitis C. World Health Organization; 2002. 69p. Available from: http://www.who.int/csr/disease/hepatitis/Hepc.pdf

45. World Health Organization. Hepatitis B. 2008. Available from: http://www.who.int/ mediacentre/factsheets/fs204/en/. Accessed December 15, 2009.

Received: 12 February 2010

Accepted: 27 October 2010 